\title{
Photosynthetic metabolism and quality of Eugenia pyriformis Cambess. seedlings on substrate function and water levels
}

\author{
SILVANA P.Q. SCALON ${ }^{1 *}$, TATIANE S. JEROMINI ${ }^{1}$, \\ ROSILDA M. MUSSURY ${ }^{2 * *}$ and DAIANE M. DRESCH ${ }^{3}$ \\ ${ }^{1}$ Universidade Federal da Grande Dourados/UFGD, Faculdade de Ciências Agrárias, \\ Rodovia Dourados Itahum, Km 12, 79804-970 Dourados, MS, Brasil \\ ${ }^{2}$ Universidade Federal da Grande Dourados/UFGD, Faculdade de Ciências Biológicas e Ambientais, \\ Rodovia Dourados Itahum, Km 12, 79804-970 Dourados, MS, Brasil \\ ${ }^{3}$ Pós-Doutoranda em Agronomia (PNPD/CAPES), Universidade Federal da Grande Dourados/UFGD, \\ Faculdade de Ciências Agrárias, Rodovia Dourados Itahum, Km 12, 79804-970 Dourados, MS, Brasil
}

Manuscript received on June 17, 2013; accepted for publication on May 5, 2014

\begin{abstract}
The aim of this research was to evaluate the quality and photosynthetic metabolism of "uvaia" seedlings (Eugenia pyriformis Cambess.) on different substrates and water regimes. The seeds were sown in tubes of $50 \times 190 \mathrm{~mm}$ in the following substrates: Sand (S), Latosol + Sand (L + S) (1:1), Latosol + Sand + Semi Decomposed Poultry Litter (L + S1 + PL) ( 1:1:0.5), Latosol + Sand + Semi Decomposed Poultry Litter (L $+\mathrm{S} 2+\mathrm{PL})(1: 2: 0.5)$, Latosol + Bioplant $^{\mathbb{B}}(\mathrm{L}+\mathrm{B})(1: 1)$, and the water levels assessed were 50, 75 and $100 \%$ of water retention capacity. At 60,90,120 and 150 days the seedlings were evaluated according to their chlorophyll index, leaf area $\left(\mathrm{cm}^{2}\right)$ and Dickson Quality Index (DQI) and at 150 days their internal concentration of carbon $\left(\mathrm{mol} \mathrm{m}^{-2} \mathrm{~s}^{-1}\right)$, stomatal conductance $\left(\mathrm{mol} \mathrm{m}^{-2} \mathrm{~s}^{-1}\right)$, transpiration rate $\left(\mathrm{mmol} \mathrm{m} \mathrm{m}^{-2} \mathrm{~s}^{-1}\right)$, photosynthesis

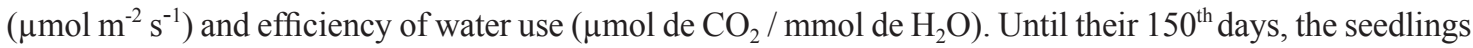
had higher quality and photosynthetic metabolism when cultured with substrates containing latosol + sand + poultry litter on the two variations assessed and water retention capacity of $50 \%$.
\end{abstract}

Key words: Cerrado, Myrtaceae, seedling production, uvaia.

\section{INTRODUCTION}

The Brazilian savanna (Cerrado) is comprised of a mosaic of physiognomies that vary from open fields to closed woodlands. The sensu stricto Cerrado vegetation is subjected to long period of low water availability during the dry season (five months

Correspondence to: Silvana de Paula Quintão Scalon E-mail: silvanascalon@ufgd.edu.br

*Programa de Pós-Graduação em Agronomia/Produção Vegetal

***Programa de Pós-Graduação em Biologia Geral/Bioprospecção or more) while the riparian and gallery forest exhibit high water availability throughout the year (Kissmann et al. 2012). This biome is endangered due to the occupation of areas for agriculture and livestock (Klink and Machado 2005).

Knowledge of methods of cultivation, such as water availability and substrate, may assure the quality of seedlings and enable successful implementation of programs for the restoration 
and revitalization of native sites, ensuring the survival and early development of seedlings during their nursery stage (Fonseca et al. 2002).

The water requirement of crops, affects the physiological and metabolic activities of plants. With a greater availability of water, the better is absorption capacity of nutrients by the roots and the higher photosynthetic efficiency, however, excess of water can cause dramatic changes in plant metabolism, reducing their growth and development. Water stress can affect root and shoot growth, both by inhibiting the internodes elongation and leaf expansion as well as accelerate their senescence and abscission (Kozlowski 1997, Taiz and Zeiger 2009, Scalon et al. 2011).

Besides water, substrate affects the growth of plants, serving as a support during the roots and nutrient supply (Zietemann and Roberto 2007). The substrate should have the ability to retain sufficient water, have a porous structure to allow good aeration and should be free from fungi and bacteria which might interfere on the growth of plants. However, the choice of substrate depends on cost and availability and various mixtures of substrates can be suggested, highlighting the use of substrates and suitable containers that allows obtaining more vigorous seedlings (Reisser Jr 2008).

The uvaia (Eugenia pyriformis Cambess. Myrtaceae) is a fruit of wide dispersion in Brazil, and its yellow, edible, sour tasting native fruit in Brazil, which can be used for making juices, vinegar and wine. Its exploitation is still carried out in an extractive form and information about production technologies are essential for its seedling propagation and rational use, however, the seedling production is hampered due to the small number of seeds per fruit (Silva et al. 2005). Seed storage under low temperature and drought, reduce germination from $77 \%$ when freshly processed to $15 \%$ and when dried to $5 \%$ of moisture content, thus indicating a recalcitrant behavior of the seed (Scalon et al. 2012) which can hamper even more the spread of this species.
The aim of the present study was to evaluate the quality and photosynthetic metabolism of uvaia seedlings (E. pyriformis) on different substrates and water regimes.

\section{MATERIALS AND METHODS}

The uvaia fruits (Eugenia pyriformis Cambess.) were collected directly from 8 sites $5 \mathrm{~km}$ from Amambai/ MS with latitude of $23^{\circ} 02^{\prime} 37^{\prime \prime} \mathrm{S}$, and longitude of $55^{\circ} 09^{\prime} 10^{\prime \prime} \mathrm{W}$ in the second half of October 2010. The fruits were processed under running water, the pulp was removed and whole seeds with no signs of injury were selected and left at room temperature in the Laboratory of Nutrition and Metabolism of Plants at UFGD (University Federal of Grande Dourados) for two days.

The seeds were sown in tubes of $50 \times 190 \mathrm{~mm}$ in the following substrates: Sand (S); Latosol + Sand (L + S) (1:1); Latosol + Sand + Semi Decomposed Poultry Litter (L + S1 + PL) (1:1:0.5); Latosol + Sand + Semi Decomposed Poultry Litter (L + S2 + PL) (1:2:0.5); Latosol + Bioplant $^{\circledR}(\mathrm{L}+\mathrm{B})(1: 1)$. The substrate $\mathrm{L}+$ $\mathrm{S} 1+\mathrm{PL}$ and $\mathrm{L}+\mathrm{S} 2+\mathrm{PL}$ contained respectively $20 \%$ and 14.3 of organic material. The soil used to prepare the substrates was collected in Dourados / MS, classified as Latosol Clay Texture. Chemical analysis of the substrates can be found in Table I.

The soil was air dried and passed through a mesh sieve of $2 \mathrm{~mm}$ prior to the mixing of fractions. The irrigation levels assessed were 50, 75 and 100\% of water holding capacity that was determined by adopting the content of water retained by the soil after each substrate disposing (Souza et al. 2000). The sand used commercially washed and poultry litter consisted of rice husks and residue remaining after the creation of four batches of broilers. The bed was stacked wet daily for about a month (Graciano et al. 2006), and subsequently used for the preparation of the substrate

At 60, 90, 120 and 150 days the seedlings were evaluated for their Chlorophyll Index (TC - SPAD) using a SPAD 502 meter; leaf area $\left(\mathrm{LA}-\mathrm{cm}^{2}\right)$ was 
TABLE I

Chemical analysis of substrates for seedling emergence and uvaia seedling production (Eugenia pyriformis Cambess.).

\begin{tabular}{|c|c|c|c|c|c|c|c|c|c|}
\hline \multirow{2}{*}{ Substrates } & $\mathrm{pH}$ & $\mathrm{P}$ & K & $\mathrm{Ca}$ & $\mathrm{Mg}$ & $\mathrm{H}+\mathrm{Al}$ & \multirow[t]{2}{*}{ L } & \multirow{2}{*}{$\begin{array}{c}\text { CEC } \\
\mathrm{mmol}_{\mathrm{c}} \mathrm{dm}^{-3} \\
\end{array}$} & \multirow{2}{*}{$\begin{array}{l}\mathrm{V} \\
\% \\
\end{array}$} \\
\hline & $\mathrm{CaCl}_{2}$ & $\mathrm{mg} \mathrm{dm}^{-3}$ & $\mathrm{mmol}_{\mathrm{c}} \mathrm{dm}^{-3}$ & \multicolumn{3}{|c|}{$\mathrm{cmolc} \mathrm{dm}^{-3}$} & & & \\
\hline$(L+S)$ & 4.4 & 0.58 & 0.3 & 1.4 & 0.6 & 1.8 & 19.9 & 3.8 & 52.0 \\
\hline$(\mathrm{L}+\mathrm{B})$ & 5.2 & 51.0 & 39.3 & 10.5 & 5.6 & 7.8 & 199.3 & 27.8 & 71.9 \\
\hline$(\mathrm{L}+\mathrm{S} 1+\mathrm{PL})$ & 6.5 & 230.9 & 30.1 & 2.9 & 2.6 & 1.5 & 85.4 & 10.0 & 84.9 \\
\hline$(\mathrm{L}+\mathrm{S} 2+\mathrm{PL})$ & 6.6 & 214.5 & 28.6 & 2.6 & 2.1 & 1.5 & 75.7 & 9.1 & 83.7 \\
\hline
\end{tabular}

$\mathrm{pH}$ in $\mathrm{CaCl} 2 \mathrm{-pH}$ in centimolar solution of chloride calcium, P - Phosphorus extracted from the soil by Mehlich, $\mathrm{K}$ - Potassium, exchangeable forms; $\mathrm{Ca}$ - Calcium, exchangeable forms, $\mathrm{Mg}$ - Magnesium, exchangeable forms $\mathrm{H}$ + Al - Potential Acidity : L - Sum of bases, CEC - Cation exchangeable capacity; V\% - Index Bases Saturation.

calculated the integrator leaf area LICOR 3000 and Dickson Quality Index (DQI) (Dickson et al. 1960) with the following equation:

$$
D Q I=\frac{T D M}{\frac{L S}{D}+\frac{D M S}{D M R}}
$$

Wherein: TDM = total dry mass; LS = length of shoot; $\mathrm{D}=$ diameter; DMS = dry mass of shoot; $\mathrm{DMR}=$ dry mass root.

At 150 days, the seedlings were evaluated for their internal concentration of carbon (ICC - mol $\mathrm{m}^{-2} \mathrm{~s}^{-1}$ ), stomatal conductance (Gs - mol $\mathrm{m}^{-2} \mathrm{~s}^{-1}$ ), transpiration rate $\left(\mathrm{E}-\mathrm{mmol} \mathrm{m}^{-2} \mathrm{~s}^{-1}\right)$, photosynthesis $\left(\mathrm{A}-\mu \mathrm{mol} \mathrm{m} \mathrm{m}^{-2} \mathrm{~s}^{-1}\right.$ ) and water use efficiency (WUE - $\mu$ mol of $\mathrm{CO}_{2} / \mathrm{mmol}$ of $\mathrm{H}_{2} \mathrm{O}$ ) using the portable photosynthesis LCi.

The statistical design was completely randomized in a split-split plot where the plot was each of the substrates, the subplot each water availability and the sub subplot each assessment time in four replicates of 20 seedlings each.

The results were subjected to analysis of variance, and when there was a significant difference the mean substrate was compared by the Tukey test and the average capacity of water retention adjusted by regression analysis, both of 0.05 significance level.

\section{RESULTS}

The chlorophyll content was higher in plants grown on 50 and $75 \%$ of water-holding capacity. In a water holding capacity of $100 \%, \mathrm{~L}+\mathrm{B}$ substract was superior to all the other substracts (Figure 1a). At 120 days the $100 \%$ water holding capacity increased the chlorophyll; however, at end of assessment there was a decrease in this value (Figures 2a, b). The substrate Latosol + Sand + Poultry Litter (1:2:0.5 and 1:1:0.5) provided greater leaf area in seedlings with water holding capacity of $50 \%$ with no significant difference between them. However, in seedlings grown in the higher water holding capacities, the leaf area was lower.

The Dickson Quality Index (DQI) was higher in the substrate Latosol + Sand + Poultry Litter $(1: 1: 0.5)$ in a water holding capacity of $50 \%$. In a $75 \%$, the DQI did not vary between Latosol + Sand + Poultry Litter (1:2:0.5) substrate and Latosol + Sand + Poultry Litter (1:1:0.5) substract. In a $100 \%$ of water holding capacity, the DQI did not vary significantly between the substracts, except for seedlings grown in sand, which showed lower DQI (Figure 1c). The substrates containing poultry litter present a higher Dickson Quality Index until $150^{\text {th }}$ day (Figure 2e), The seedlings did not achieve maximum quality until the $150^{\text {th }}$ day (Figures 2e, f). 
A)

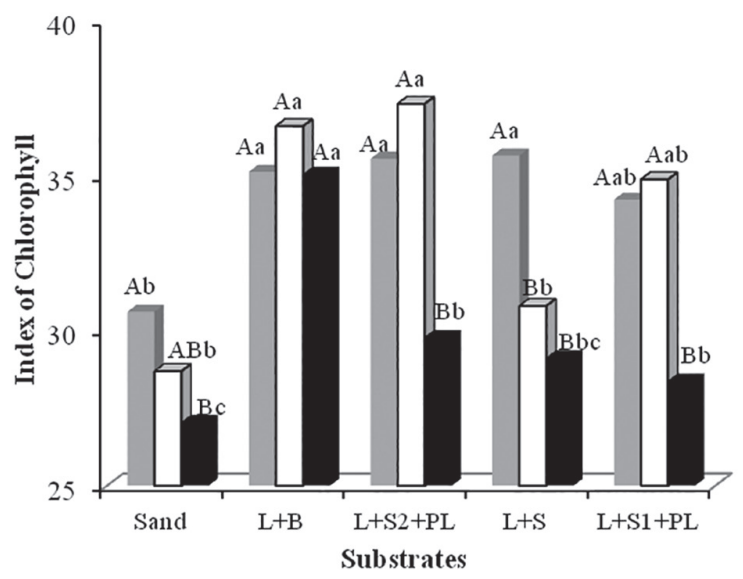

B) $\quad \square 50 \% \quad \square 75 \% \quad-100 \%$

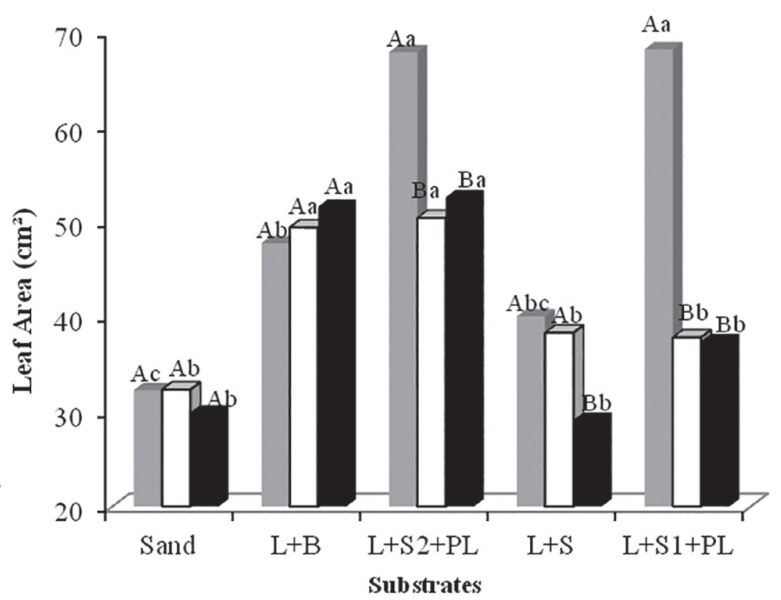

C)

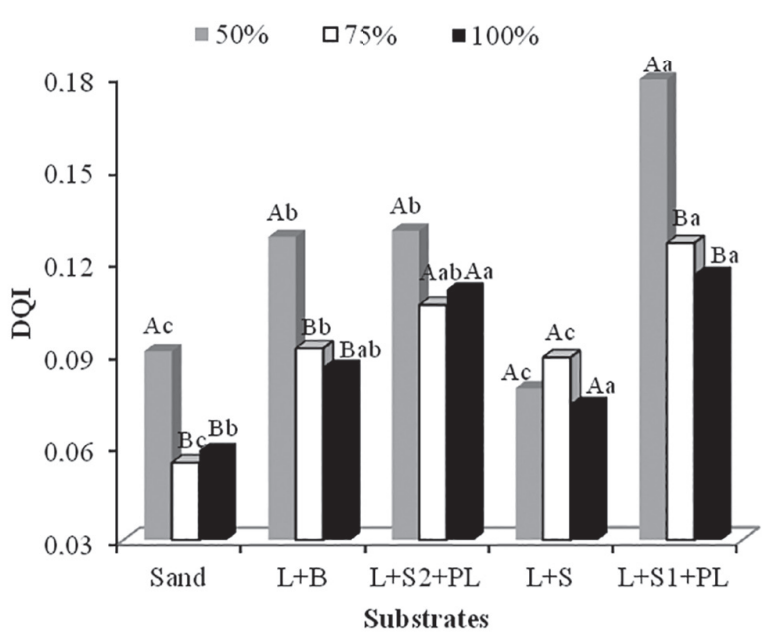

Figure 1 - Index of Chlorophyll (a), Leaf Area (b) and Dickson Quality Index (c) of uvaia seedlings (Eugenia pyriformis Cambess.), due to different substrates and water holding capacity (WHC). Means with the same capital letter do not differ significantly from the levels of water retention capacity within the same substrate and lowercase for the level of water holding capacity between different substrates by Tukey test at $5 \%$ significance.

At 150 days, the internal carbon concentration (ICC) and stomatal conductance (Gs) was higher in lower water holding capacity, while ICC was higher in $\mathrm{S}$ and $\mathrm{L}+$ Bio substracts and Gs was higher in L + S1 + PL substract (Figures 3a, b). Transpiration was higher in seedlings grown in greater water holding capacity, on average higher in seedlings grown on substrates containing poultry litter in two proportions and in the mixture of Sand and Latosol which did not vary from one to the other (Figure 3d). The photosynthetic rate was higher in less water availability in all substrates, except in sand (Figure 3c).

The highest photosynthetic rate was observed in seedlings grown in trays containing poultry litter to $50 \%$ of water holding capacity, but most internal concentration of carbon did not correspond to the same treatments (Figures 3a, c). The seedlings showed more water use efficiency (WUE) when grown with less water availability, except in sand substrate (Figure 3e). 
A)
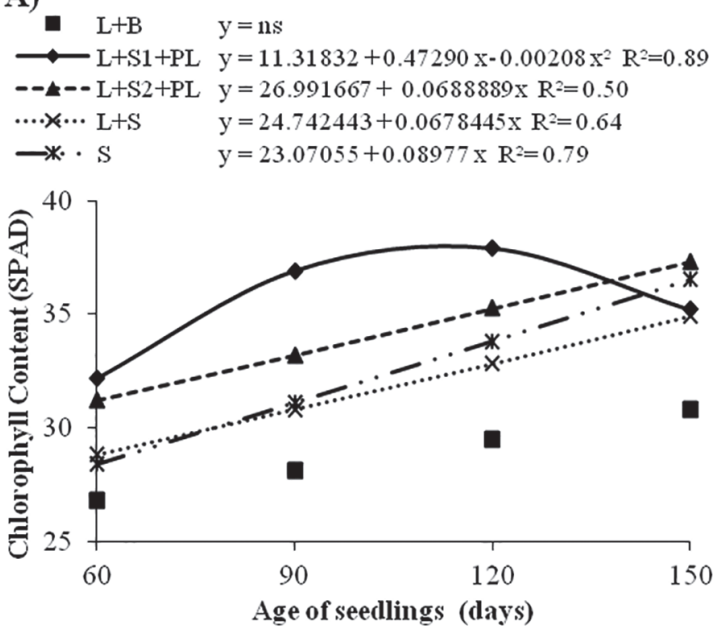

C) $\begin{array}{ll}-\square \cdot S & y=1822066+0.12660 \times R^{2}=0.77 \\ \longrightarrow L+B & y=38.40077+0.10623 \times R^{2}=0.52 \\ \longrightarrow-\mathrm{L}+\mathrm{S} 2+P L & y=2.84911+0.51506 \times \mathrm{R}^{2}=0.93 \\ \cdots \times \cdots \text { L+S } & y=32.94955+0.02718 \times \mathrm{R}^{2}=0.11 \\ \longrightarrow * \cdot \mathrm{L}+\mathrm{S} 1+\mathrm{PL} & \mathrm{y}=-9.31844+0.54494 \times \mathrm{R}^{2}=0.99\end{array}$

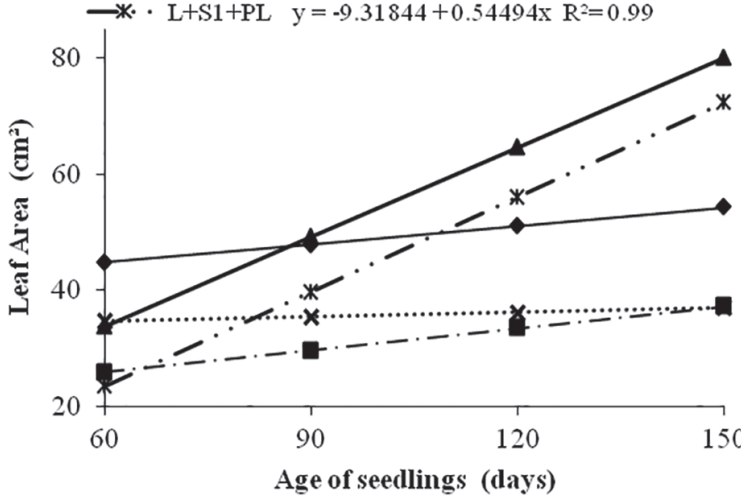

E)
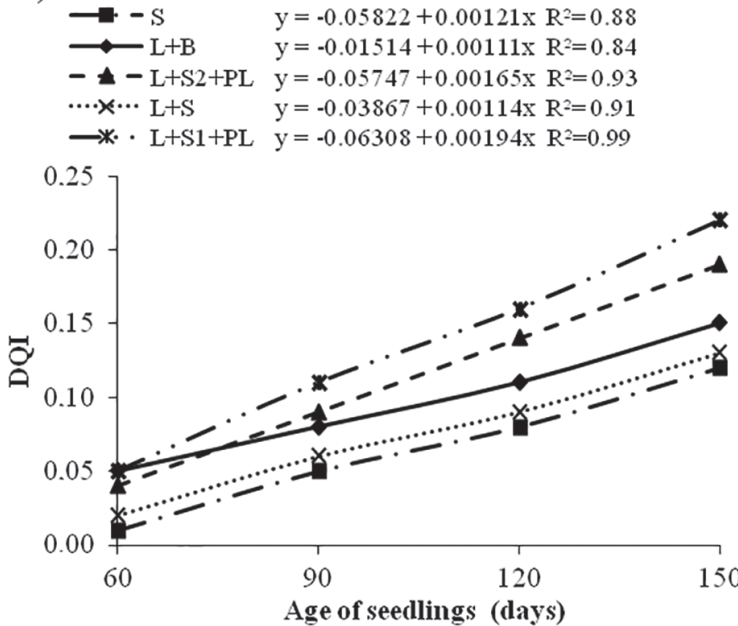

B)
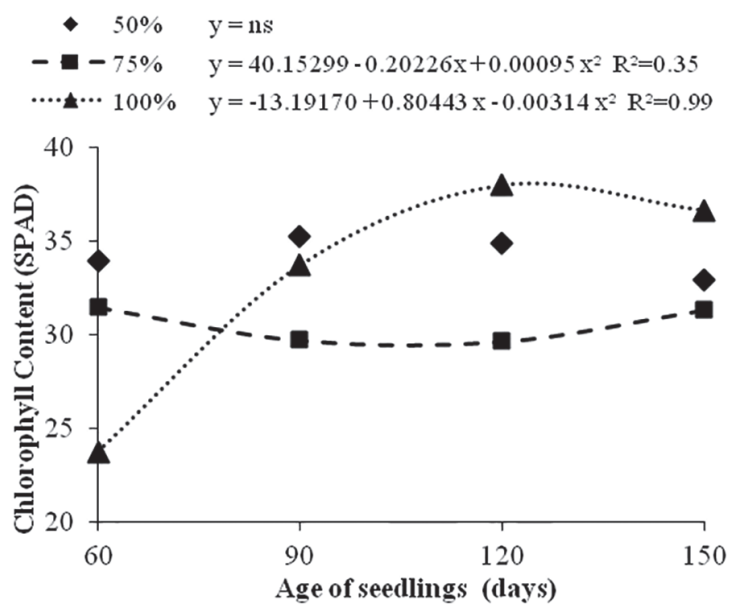

D)

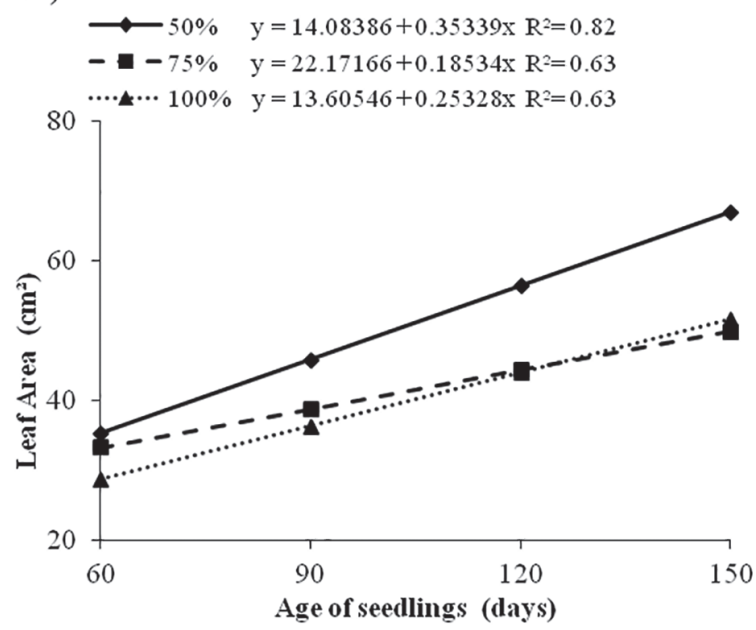

F)
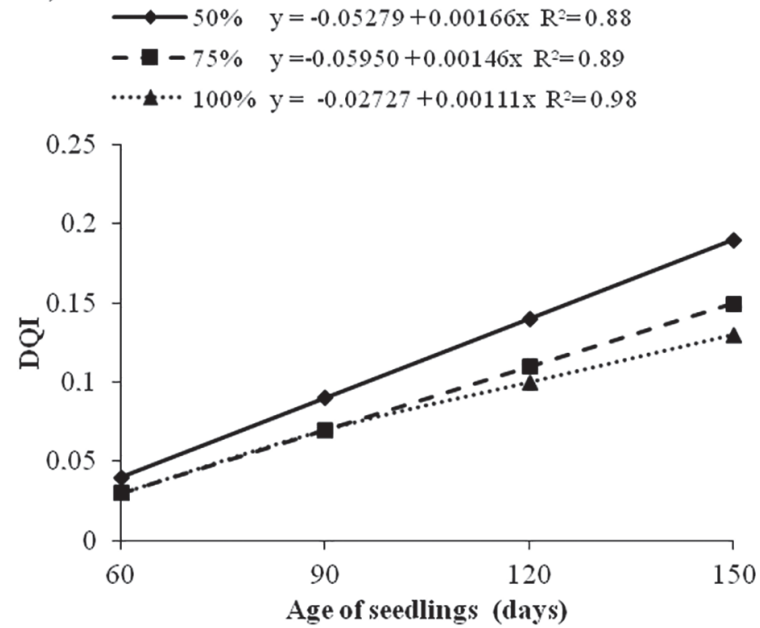

Figure 2 - Chlorophyll Content, Leaf Area and Dickson Quality Index in uvaia seedlings (Eugenia pyriformis Cambess.) in substrates functions (a, c, e) and water holding capacity (b, d, f). 
A)

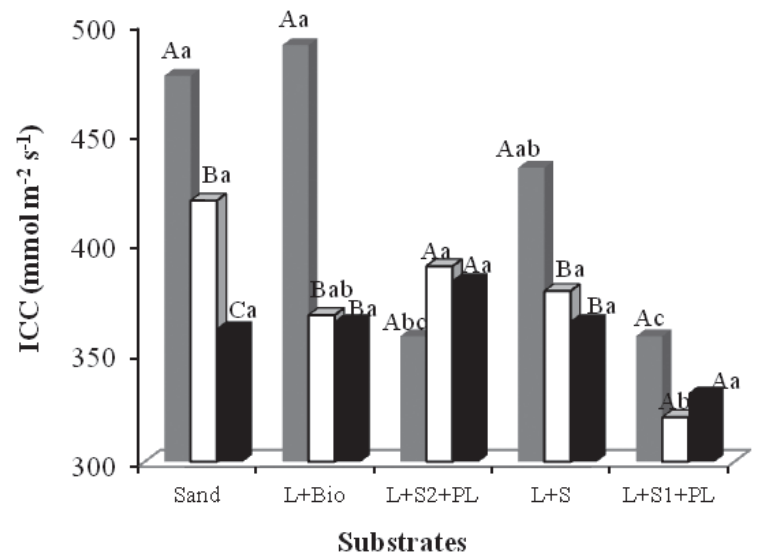

C)

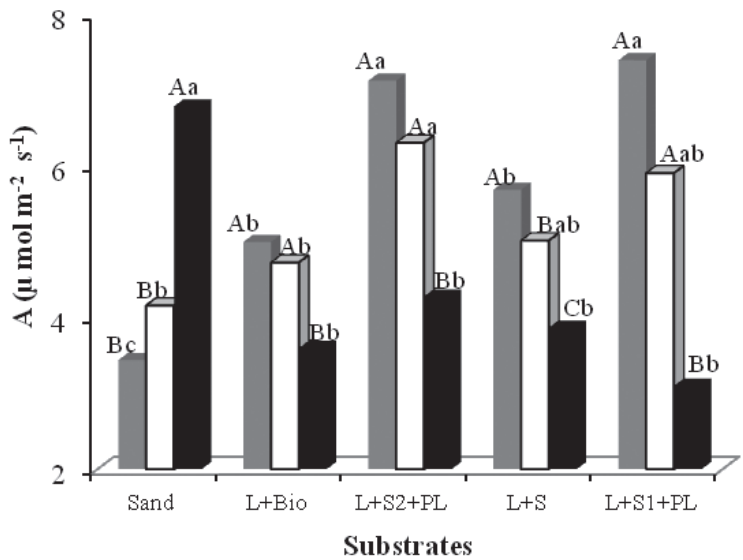

B) — $50 \% \quad$ $75 \% \quad \square=100 \%$

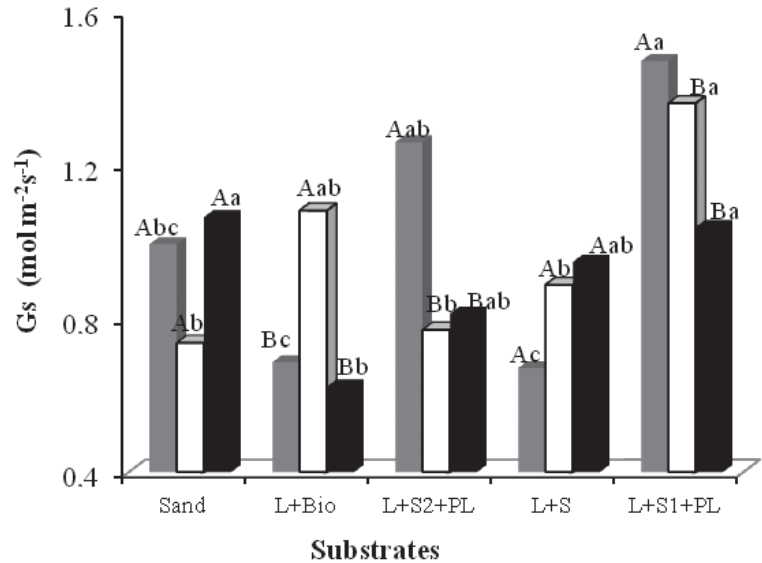

D)

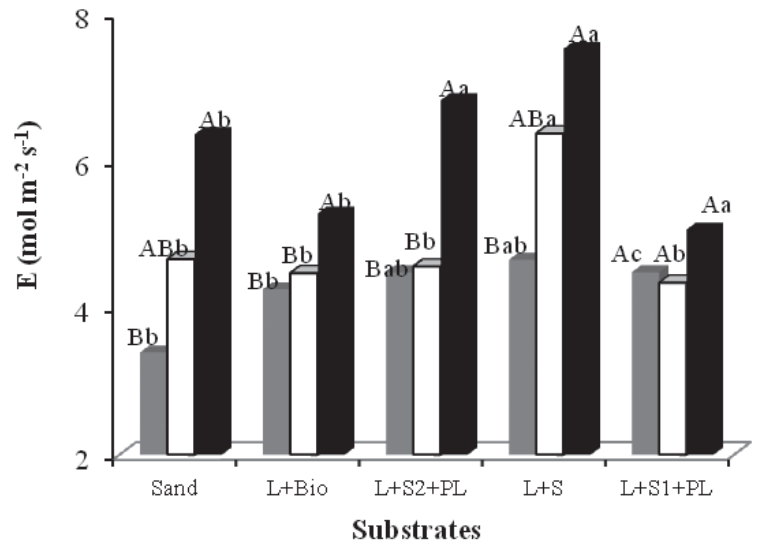

E)

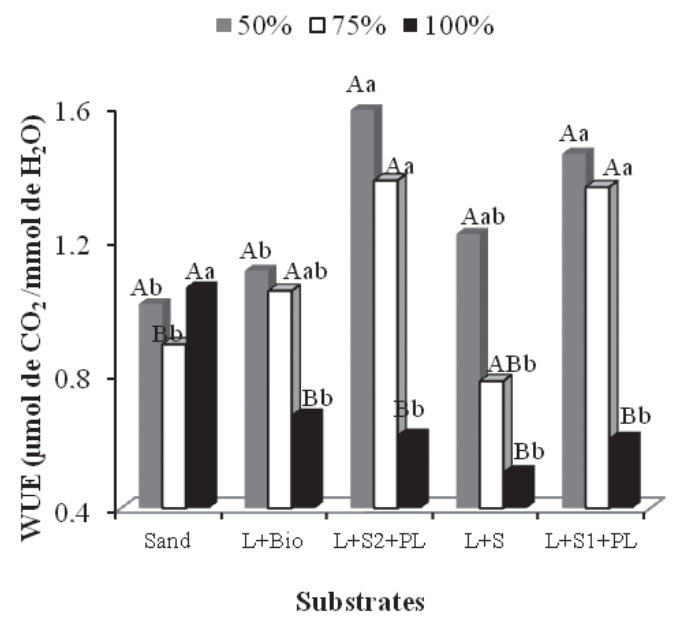

Figure 3 - Internal Carbon Concentration (a), Stomatal Conductance (b), Photosynthesis (c), Transpiration (d) and water use efficiency (e) of uvaia seedlings (Eugenia pyriformis Cambess.) at 150 days due to different substrates and water holding capacity (WHC). Means with the same capital letter do not differ significantly from the levels of water retention capacity within the same substrate and lowercase for the level of water holding capacity between different substrates by Tukey test at $5 \%$ significance. 


\section{DISCUSSION}

The reduced rates of chlorophyll with the increasing of water availability may be due to the lower nitrogen content in the leaves under conditions of flooding and drought. The decrease in oxygen content causes restrictions in plant metabolism, due to the reduced activity of the enzyme nitrate reductase, impairing the uptake and transport of ions and therefore the reduction of nutrient levels in the shoots of the plant, including nitrogen (Floss 2006).

The larger increase in leaf area observed in the substrate containing poultry litter may be because of the use of organic waste especially at the beginning of the cycle, stimulating development of the shoot, in terms of height and leaf area. This occurs because adding organic matter to the soil improves their physical characteristics and retains more moisture throughout the day (Graciano et al. 2006), which maintains higher water availability to the plant without causing anoxia.

The tree species response to water availability varies. Lenhard et al. (2010) observed lower leaf area of ironwood seedling (Caesalpinia ferrea Mart. ex Tul. var. leiostachya Benth.) when irrigated with low water availability $(12.5 \%$ of water retention) and under flooding, and higher leaf area under $70 \%$ of water retention. However, for mastic seedlings (Myracrodruon urundeuva All.) (Figueirôa et al. 2004) and yellow ipê seedlings (Tabebuia aurea (Manso) Benth. and Hook. f. ex S. Moore) (Cabral et al. 2004) the leaf area was higher and did not vary among the largest water availability tested (50 and $75 \%$ for mastic and 50 and $100 \%$ for yellow ipê). Decrease in plant height and the suppression of leaf formation and expansion are common responses to flooding conditions and often result in massive decrease of plant biomass (Kozlowski 1997).

The lower growth of leaf area and lower index of chlorophyll found in uvaia seedlings (E. pyriformis) grown in $100 \%$ of the capacity of water retention may be due to soil saturation which inhibiting the leaf expansion, also affect plant growth reducing root and shoot. In fact, most of the Cerrado species do not tolerate waterlogged soils (Amorim and Batalha 2006).

The species sensitive to flood stress develop symptoms, which result primarily from disturbances caused by hypoxia or anoxia in roots. The most common are the abscission of leaves, flowers and fruits and chlorotic leaves (Kozlowski 1997).

The seedlings did not reach maximum capacity until the $150^{\text {th }}$ day because they still presented growth that could be viewed by the linear equations that fit the average. These results suggest that the culture conditions evaluated did not prevent the development of seedlings and that may continue for a long time under the same conditions. The Dickson Quality Index is a balanced formula, which includes the morphological characteristics of shoot height, stem diameter, total dry mass, dry mass of shoot and root and as greater the value of this index, better the seedling quality, indicating the robustness and balance in the distribution of biomass in the seedlings (Gomes 2001, Fonseca et al. 2002).

Based on the results, the best substrate for the production of uvaia seedlings (E. pyriformis) was the one containing 33 at $50 \%$ organic waste, although the benefits of using poultry litter on seedling production remains uncertain. The substrate which consisted of $60 \%$ subsoil and $40 \%$ of poultry litter was recommended for the production of tamarind seedlings (Tamarindus indica L.) (Pereira et al. 2010), mangaba (H. speciosa Gomes) (Silva et al. 2009) and papaya (Carica papaya L.) (Trindade et al. 2000). However, D.M. Dresch (unpublished data) found that the addition of poultry litter hampered the development of guavira seedlings (Campomanesia adamantium Cambess.) compared to the use of Latosol and mixtures of soil and soil + sand + Plantmax $^{\circledR}$. Similarly, some native species of the Midwest, such as the mangaba (H. speciosa), baru (Dipteryx alata Vog.) and cagaita (Eugenia dysenterica DC.) developed better when the substrate was devoid of any source 
of organic matter (Paiva Sobrinho et al. 2010). These results suggest that it is not possible to generalize the beneficial effect of the addition of organic waste in the production of seedlings and that for some species the results are still contradictory.

The greater efficiency of water use in seedlings with $50 \%$ capacity retention of water are due to higher photosynthetic activity of plants in this condition, suggesting that lower availability of water is not water limitation for this species.

Similar results were observed by Scalon et al. (2011) who evaluated the photosynthetic metabolism and transpiration of mutambo seedlings (Guazuma ulmifolia Lam.) and concluded that, although no significant difference was found between the efficiency of water use within the four levels of irrigation assessed $(12.5,25,50$ and $100 \%)$, stomatal conductance and photosynthesis were higher and did not vary significantly between 25,50 and $100 \%$ of water retention capacity. However they noted that the transpiration was higher and did not vary between 50 and $100 \%$ of water retention, showing that the species also presents high efficiency in the use of water under low water availability.

These results suggest that $50 \%$ of water retention capacity can be used in the initial stage of various seedlings species, as well as for the growth of mastic (M. urundeuva) (Figueirôa et al. 2004) and yellow ipê (T. aurea) (Cabral et al. 2004).

Normally in a situation of low water availability in the soil, the plants reduce the loss of water by reducing stomatal conductance. Similar responses to those found for uvaia (E. pyriformis) were observed by Rocha and Moraes (1997) in Stryphnodendron adstringens http://www.tropicos.org/Name/13001565 (Mart.)Covilleplants, nativespecies from the Midwest, which showed higher efficiency of water use when the stomatal conductance and transpiration were lower, although for the uvaia the stomatal conductance was higher in the lower water availability evaluated and when grown in a substract with organic matter. Probably, these species are well adapted to disability or lower water availability subject to the availability of organic matter.

However, the condition of $100 \%$ of water retention capacity can be considered stressful for uvaia seedlings (E. pyriformis) that responded similarly to some species in situations of flooding. Low gs values soon after flooding have been widely reported for many flood-tolerant or non flood-tolerant species? (Mielke et al. 2003, Medina et al. 2009, Oliveira and Joly 2010). The rapid decrease of $g s$ may be particularly important for plant survival under flooding because it prevents excessive transpiration in conditions in which the water uptake capacity is being impaired. When the stomatal opening is reduced, the flow of water vapor decreases proportionally in higher extent than the decrease of the flow of $\mathrm{CO}_{2}$ absorption. In an extreme case, when the loss by transpiration can irreversibly affect the growth or survival of the plant, the stomata tends to close completely, limiting the supply of $\mathrm{CO}_{2}$ (Plaut 1994).

According to Souza et al. (2012) the Cerrado soil is composed of about $46 \%$ of latosol. Latosol is characterized by a low availability of nutrients, acid reaction, low cation exchange capacity and low organic matter content, which among other features, lead to a poor absorption of nutrients by plants, especially nitrogen $(\mathrm{N})$ and phosphorus $(\mathrm{P})$.

Regarding the substrate, these results reinforce the hypothesis that the addition of poultry litter could have reduced evaporation and maintained the lowest temperatures in the soil in relation to the external environment, thus inducing, better heatwater balance in the plant and higher water retention capacity of soil. This effect increased the absorption capacity of water and nutrients by plants, to improve physical, chemical and biological soil (Heredia Zárate et al. 2004), contributing to raise the $\mathrm{pH}$ near neutrality, raising the phosphorous content (Table I).

At 150 days of age, the uvaia seedlings ( $E$. pyriformis) had higher quality and metabolic responses when cultured with substrates containing Latosol + Sand + Poultry Litter in two variations evaluated and water retention of $50 \%$. 


\section{ACKNOWLEDGMENTS}

We thank the Conselho Nacional de Desenvolvimento Científico e Tecnológico (CNPq) for the scholarship concession and Fundação de Apoio ao Desenvolvimento do Ensino, Ciência e Tecnologia do Estado de Mato Grosso do Sul (FUNDECT) for the financial support.

\section{RESUMO}

Objetivou-se no presente trabalho avaliar a qualidade e o metabolismo fotossintético das mudas de uvaia (Eugenia pyriformis Cambess.) em diferentes substratos e regimes hídricos. A semeadura foi realizada em tubetes de $50 \mathrm{x}$ $190 \mathrm{~mm}$ nos seguintes substratos: Areia (A), Latossolo $+\operatorname{areia}(\mathrm{L}+\mathrm{A})(1: 1)$, Latossolo + areia + cama de frango semidecomposta $(\mathrm{L}+\mathrm{A} 1+\mathrm{CF})(1: 1: 0,5)$, Latossolo + areia + cama de frango semidecomposta $(\mathrm{L}+\mathrm{A} 2+$ CF) (1:2:0,5), Latossolo + Bioplant ${ }^{\circledR}(\mathrm{L}+\mathrm{B})(1: 1)$ e os níveis de irrigação avaliados foram 50, 75 e 100\% da capacidade de retenção de água. Aos 60, 90, 120 e 150 dias de idade as mudas foram avaliadas quanto ao índice de clorofila; a área foliar $\left(\mathrm{cm}^{2}\right)$ e o índice de qualidade de Dickson (IQD) e aos 150 dias de idade foram avaliadas a concentração interna de carbono $\left(\mathrm{mol} \mathrm{m}^{-2} \mathrm{~s}^{-1}\right)$, condutância estomática $\left(\mathrm{mol} \mathrm{m}^{-2} \mathrm{~s}^{-1}\right)$, taxa de transpiração $\left(\mathrm{mmol} \mathrm{m}^{-2}\right.$ $\left.\mathrm{s}^{-1}\right)$, fotossíntese $\left(\mu \mathrm{mol} \mathrm{m} \mathrm{m}^{-2} \mathrm{~s}^{-1}\right)$ e eficiência no uso da água ( $\mu \mathrm{mol}$ de $\mathrm{CO}_{2} / \mathrm{mmol}$ de $\mathrm{H}_{2} \mathrm{O}$ ). Até os 150 dias de idade, as mudas apresentaram maior qualidade e metabolismo fotossintético quando cultivadas com substratos contendo Latossolo + areia + cama de frango nas duas variações avaliadas e na capacidade de retenção de água de 50 \%.

Palavras-chave: Cerrado, Myrtaceae, produção de mudas, uvaia.

\section{REFERENCES}

AMORIM PK AND BATALHA MA. 2006. Soil characteristic of a hyperseasonal cerrado compared to a seasonal cerrado and a flooodplain grassland: implications for plant community structure. Braz J Biol 66: 661-670.

CABral EL, Barbosa DCA AND Simabukura EA. 2004. Crescimento de plantas jovens de Tabebuia aurea (Manso) Benth. \& Hook. f. ex S. Moore submetidas a estresse hídrico. Acta Bot Bras 18: 241-251.
DiCKSON A, LEAF AL AND HoSNER JF. 1960. Quality apprasial of withe spruce and White pine seedling stock in nurseries. For Chron 36: 10-13.

FigueIrôA JM, BARBosA DCA AND SIMABUKURU EA. 2004. Crescimento de plantas jovens de Myracrodruon urundeuva Allemão (Anacardiaceae) sob diferentes regimes hídricos. Acta Bot Bras 18: 573-580.

FLOSS EL. 2006. Fisiologia das plantas cultivadas: o estudo do que está atrás do que se vê. $3^{\mathrm{a}}$ ed., Passo Fundo: Editora Universidade de Passo Fundo, 751 p.

Fonseca EP, VALERI SV, MigliorançA E, Fonseca NAN AND COUTO L. 2002. Padrão de qualidade de mudas de Trema micrantha (L.) Blume, produzidas sob diferentes períodos de sombreamento. Rev Arvore 26: 515-523.

GoMES JM. 2001. Parâmetros morfológicos na avaliação da qualidade de mudas de Eucalyptus grandis, produzidas em diferentes tamanhos de tubete e de dosagens de N-P-K. Tese (Doutorado em Ciência Florestal) - Universidade Federal de Viçosa, Viçosa, MG, 126 p.

GRACIANO JD, HEREDIA ZÁrATE NA, VIEIRA MC, Rosa YBCJ, SEDIYAMA MAN AND RoDRIGUES ET. 2006. Efeito da cobertura do solo com cama-de-frango semidecomposta sobre dois clones de mandioquinha-salsa. Acta Sci Agron 28: 367-376.

HEREDIA ZÁrate NA, VIEIRA MC, Rosa JUNIOR EJ AND SILVA CG. 2004. Forma de adição ao solo da cama-de-frango de corte semidecomposta para produção de taro. Pesqui Agropecu Trop 34: 111-117.

KisSMANN C, TOZZI HH, MARTINS S AND HABERMANN G. 2012. Germination performance of congeneric Styrax species from the Cerrado sensu lato areas and their distribution pattern in different physiognomies. Flora 207: 673-681.

KLINK CAAND MACHADO RB. 2005. Conservation of Brazilian Cerrado. Conserv Biol 19: 707-713.

KOZLOWSKI TT. 1997. Responses of woody plants to flooding and salinity. Tree Physiol 1: 1-29.

LENHARD NR, SCALON SPQ AND Novelino JO. 2010. Crescimento inicial de mudas de pau ferro (Caesalpinia ferrea MART. ex Tul. var. leiostachya Benth.) sob diferentes regimes hídricos. Cienc Agrotec 34: 870-877.

Medina CL, SANChes MC, TUCCI MLS, Sousa CAF, CuZzUOL GRF AND JOLY CA. 2009. Erythrina speciosa (Leguminosae-Papilionoideae) under soil water saturation: morphophysiological and growth responses. Ann Bot 104: 671-680.

Mielke MS, Almeida AAF, Gomes FP, Aguilar MAG AND MANGABEIRA PAO. 2003. Leaf gas exchange, chlorophyll fluorescence and growth responses of Genipa americana seedlings to soil flooding. Environ Exp Bot 50: 221-231.

OLIVEIRA VC AND JOLY CA. 2010. Flooding tolerance of Calophyllum brasiliense Camb. (Clusiaceae): morphological, physiological and growth responses. Trees 24: $185-193$.

PaIVA Sobrinho S, LuZ PB, Silveira TLS, RAMOs DT, NEVES LG AND BARELLI MAA. 2010. Substratos na produção de mudas de três espécies arbóreas do cerrado. Agraria 5: 238-243. 
Pereira PC, Melo B, Freitas RS, Tomaz MA AND Freitas CJP. 2010. Mudas de tamarindeiro produzidas em diferentes níveis de matéria orgânica adicionada ao substrato. Rev Verde 5: 152-159.

PLAUT Z. 1994. Photosynthesis in plant/crops under water and salt stress. In: PESSARAKLI M (Ed), Handboook of plant and crop stress. New York: Marcel Dekker, p. 587-603.

ReisSER Junior C, MEdeiros CAB AND RAdin B. 2008 Produção de mudas em estufas plásticas. Pelotas: 15 Embrapa Clima Temperado, $5 \mathrm{p}$.

RochA AMS AND MORAES JAPV. 1997. Influência do estresse hídrico sobre as trocas gasosas em plantas jovens envasadas de Stryphnodendron adstringens (Mart.) Coville. Braz J Plant Physiol 9: 41-46.

SCALON SPQ, MusSURY RM, EUZÉBIO VLM, KodAMA FM AND KISSMANN C. 2011. Estresse hídrico no metabolismo e crescimento inicial de mudas de mutambo (Guazuma ulmifolia Lam.). Cienc Florest 21: 657-665.

Scalon SPQ, Neves EMS, Maseto TE and Pereira ZV. 2012. Sensibilidade à dessecação e ao armazenamento em sementes de Eugenia pyriformis Cambess. (Uvaia). Rev Bras Frutic 34: 269-276.

Silva EA, Maruyama WI, Oliveira AC and Bardiviesso DM. 2009. Efeito de diferentes substratos na produção de mudas de mangabeira (Hancornia speciosa). Rev Bras Frutic 31: 925-929.
SiLVA VC, BILIA DAC AND BARBEDO CJ. 2005. Fracionamento e germinação em sementes de Eugenia. Rev Bras Sementes 27: 86-92.

SOUZA CC, OliveIRAFA, SILVA IF AND AMORIM NETO MS. 2000 Avaliação de métodos de determinação de água disponível e manejo da irrigação em solo roxa sob cultivo de algodoeiro herbáceo. Rev Bras Enga Agric Ambient 4: 338-342.

Souza NH, MARChETTI ME, CARNEVALI TO, RAMOS DD, SCALON SPQ AND SILVA EF. 2012. Estudo nutricional da canafístula (II): eficiência nutricional em função da adubação com nitrogênio e fósforo. Rev Árvore 36: 803-812.

TAiz L And ZeIger E. 2009. Fisiologia Vegetal. $3^{\mathrm{a}}$ ed., Porto Alegre: Artmed, $848 \mathrm{p}$.

Trindade AV, Farias NG AND Almeida FP. 2000. Uso de esterco no desenvolvimento de mudas de mamoeiro colonizadas com fungos micorrízicos. Pesqui Agropecu Bras 35: 1389-1394.

ZIETEMANN C AND RoBerTo SR. 2007. Produção de mudas de goiabeira (Psidium guajava L.) em diferentes substratos. Rev Bras Frutic 29: 137-142. 